\title{
FINANCIAL LITERACY AND FINANCIAL INCLUSION ON THE FINANCIAL PLANNING OF THE CITY OF PALEMBANG
}

\author{
Wani Fitriah, Anggreany Hustia, Ranggawuni Ahdan \\ Universitas Muhammadiyah Palembang, \\ Palembang, Indonesia
}

\begin{abstract}
This study is aimed to determine the influence of financial literacy and financial inclusion on the financial planning of the city of Palembang. This research used an infinite population with a sample of 200 respondents. The data used is primary data collected using questionnaires. The analysis technique used was the test instrument; classic assumption test; multiple linear regression analysis; hypothesis F-test and t-test; and the coefficient of determination. The results of the F-test for financial literacy and financial inclusion show a positive and significant effect on the financial planning of the city of the Palembang. The results of the t-test for the financial literacy show a positive and significant influence on the financial planning of the city of Palembang. However, financial inclusion had no influence and no significance on the financial planning of the city of the Palembang.
\end{abstract}

Keywords: financial literacy, financial inclusion, financial planning

\section{INTRODUCTION}

The rapidly changing economic conditions today are often unpredictable. This causes difficulties for the general public to be able to plan their financial condition either in the short term or long term. With this uncertainty, it is very important to have good financial planning for economic conditions in the future. This good financial planning can maintain and prevent the occurrence of unwanted conditions in the community.

Financial planning is a derivative of financial management. Financial management is a science that learns about planning, analyzing, and controlling

\footnotetext{
*Corresponding Author.

e-mail: darmayanti@um-palembang.ac.id
} 
financial activities (Suad Husnan and Enny Pudjiastuti, 2016: 4). Financial planning is an activity to estimate the position and financial condition of the company in the future (it can be short-term or long-term). The financial plan is based on a series of assumptions (scenarios), both related to the relationship between financial variables, and financial decisions (Suad Husnan and Enny Pudjiastuti, 2016: 88). Some financial planning, according to Randy Lukmanto (2014:2), can be insurance, pension funds, investments, debt, taxes, or protection.

One of the important things in drawing up such a financial plan is the public's understanding of financial literacy. According to the Australian Securities and Investment Commission (ASIC, 2014), financial literacy is defined as a combination of financial knowledge, skills, attitudes, and behaviors necessary to make sound financial decisions, based on personal circumstances, to improve financial wellbeing. This shows that financial literacy is a major contributor in improving prosperity.

The achievement of public prosperity must be supported by other factors, including inclusive finance and access to financial services products, adequate consumer protection, and robust regulation to ensure financial markets run fairly and transparently (Kusumaningtuti S. Soetiono and Cecep Setiawan, 2018: 8). Thus, in addition to the understanding of the community related to financial literacy, other factors that contribute to the community in conducting financial planning are financial inclusion factors. Financial inclusion is the availability of access to various institutions, financial products, and services that aim to avoid any more obstacles that occur so that it can be reached at a low cost in order to improve the welfare of the community.

Based on the results of the National Survey of Financial Literacy (SNLIK) conducted by the Financial Services Authority (OJK) in 2019, the financial literacy index and the financial inclusion index are shown to have reached $38.03 \%$ and $76.19 \%$, respectively. The figure had increased compared to the results of the OJK survey in 2016, having financial literacy index and the financial inclusion index of $29.7 \%$ and $67.8 \%$, respectively. This indicates that there has been an increase in people's financial understanding (literacy) by $8.33 \%$ as well as increased access to financial products and services (financial inclusion) by $8.39 \%$. 
In addition to the survey data in this study, a pre-survey was given to 30 people in Palembang city as the object studied. This pre-survey asked which of financial planning, financial literacy, and financial inclusion are considered influential for the community. From the results of the pre-research, it can be seen that financial planning is influenced by income level as much as $27 \%$, age as much as $10 \%$, gender as much as $23 \%$, education as much as $17 \%$, family finance as much as $13 \%$, and personal finance as much as $10 \%$. Thus, it is stated that the level of income earned by the community further influences a person to do financial planning. Second, the level of financial literacy of the community is influenced by financial knowledge as much as $43 \%$, financial skills as much as $10 \%$, financial confidence as much as $13 \%$, financial attitude as much as $17 \%$, and financial behavior as much as $17 \%$. It can be seen that the high indicator of public financial knowledge shows that most people express the importance of understanding financial knowledge in order to live prosperously. Third, the level of financial inclusion of the community is influenced by access as much as $33 \%$, availability as much as $20 \%$, usage as much as $24 \%$, and quality as much as $23 \%$. It appears that access to services and products is the indicator that is considered to affect financial inclusion the most.

There are some previous researches that have examined the same variables. One of which is the research of Iko Putri Yanti W. (2019) which stated that there is an influence of financial inclusion on financial planning. Another is the research by Sobaya S., Hidayanto M., Safitri J. (2016), Dahlia Bonang (2019), and by Fakhriyah Arfianti Saputri, Rr. Iramani (2019) which stated that financial literacy has an effect on financial planning. Another research on the same variables is done by Eka Desy Purnama and Fetrik Erwanto Simarmata (2021) but the results said that financial literacy has no influence on the financial planning of employees of Bank Panin KCU Plaza Pasifik Kelapa Gading.

These researches departed from the phenomenon of how financial planning is very important in order to minimize unwanted occurrences as a result of the increasingly difficult economy today. Therefore, people need to understand financial literacy and financial inclusion in order to make good financial planning. In addition, against the background of the differences in the results of previous researches, the author is interested in conducting this research with the objects of Palembang City community. 


\section{LITERATURE REVIEW}

\subsection{Financial Planning}

The definition of financial planning according to the Financial Planning Standards Board Indonesia is the process of achieving one's life goals through integrated and planned financial management (Palameta; Gyarmati, 2016).

Prita Hapsari Ghozie (2019:62) in her book Make it happen! The Smart Book of Financial Plans for Realizing Dreams defines financial planning as a process in which an individual tries to fulfil his financial goals through the development and implementation of a comprehensive financial plan. Good financial planning will produce a clear financial plan and facilitate the plan owner to achieve his financial goals. This financial plan is similar to a blueprint showing where the financial condition of an individual or family will go.

According to Wibawa (2003), the benefits of financial planning are as follows: first, financial planning does not promise people to get rich suddenly, but rather as disciplinary measures to control themselves and provide the best future financial conditions for themselves and their families efficiently and effectively in accordance with current financial capabilities. Second, to secure financial guarantee. Third, family financial planning will help efficiently and effectively achieve financial goals.

\subsection{Financial Literacy}

In the 2013 National Strategy for Indonesian Financial Literacy, the financial services authority uses the term financial literacy as a series of processes or activities to increase knowledge, confidence, and skills of consumers and the wider community so that they are able to better manage finances (OJK, 2013).

This definition has been refined in OJK Regulation No. 76 of 2016 and in the National Strategy for Indonesian Financial Literacy (2017 Revision). The refinement of financial literacy is carried out by adding aspects of financial attitudes and behavior in addition to knowledge, skills, and belief in financial institutions, products, and services.

The definition of financial literacy becomes knowledge, skills, and beliefs, which influence attitudes and behavior to improve the quality of decision making and financial management in order to achieve prosperity (POJK, 2016). 
Remund in Eka D.P; Fetrik E.S. (2021:1569) stated that financial literacy is a measurement of a person's understanding of financial concepts, and has the ability and confidence to manage personal finance through proper short-term decision making, long-term financial planning, and attention to economic events and conditions.

According to Cecep Setiawan and Kusumaningtuti S. Soetiono (2018: 74), indicators used in measuring the level of financial literacy are financial knowledge, financial behavior, and financial attitudes that will produce a national level of financial literacy.

\subsection{Financial Inclusion}

In OJK regulations, financial inclusion is defined as the availability of access to various financial institutions, products and services in accordance with the needs and abilities of the community in order to improve the welfare of the community (POJK, 2016).

According to Cecep Setiawan and Kusumaningtuti S. Soetiono (2018: 107), indicators in financial inclusive measurement can be explained as follows: first is access, a dimension used to measure the ability in the use of formal financial services, which can finally show the occurrence of potential barriers to using bank accounts. Here, the ability of a customer in accessing banking services anytime and anywhere becomes an important aspect in this financial inclusion strategy. Second is usage, a dimension used to measure the capability to use financial products and services related to, among others, regularity, frequency, and length of use. Third is quality, a dimension used to determine whether the availability of attributes of products and services of a financial institution has met the needs of its customers or not.

\subsection{Hypothesis}

Based on the descriptions that have been discussed, the hypothesis in this study can be formulated as follows: there is an effect of financial literacy and financial inclusion on the financial planning of the city of the Palembang. 


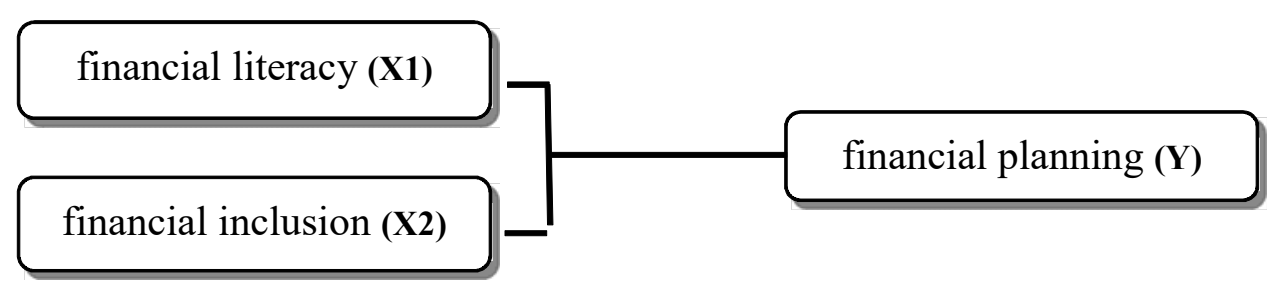

Picture 1 Frame of Mind in this Study

\section{RESEARCH METHODOLOGY}

The methodology used by the author in this study is associative, which is to determine the relationship between the influence of financial literacy and financial inclusion on the community financial planning in Palembang. This research was conducted on communities in the city of Palembang, South Sumatra Province.

The population used in this study is an infinite population, namely housewives in Palembang City who already have an income, either from their husbands or from their own occupations. The sample in this study were some of the housewives in Palembang City. The sampling technique used in this study was accidental sampling.

The analysis technique used in this research is descriptive and inferential statistics. Descriptive statistics describes data seen from the average value (mean), standard deviation, variance, maximum, minimum, sum, range, and skewness. The inferential analysis in this study is the classic assumption test (normality, multicollinearity), multiple regression test, hypothesis testing, and the coefficient of determination. The analysis techniques used in this study will be assisted by the Statistical Program for Special Science (SPSS) version 25. Before conducting the analysis, in accordance with the requirements of the OLS (ordinary least square) method, first the instruments used will be tested first (validity test and reliability test).

\section{RESULT}

\subsection{Instrument test}

Instrument tests conducted in this study are validity tests and reliability tests. The first is a validity test. The validity test is performed by comparing the 
corrected item-total correlation value of each item statement with table $\mathrm{r}$ value. If the corrected item-total correlation value $>$ table $r$ value of 0.3061 then the statement is declared as valid and vice versa. The points of statement related to financial literacy amounted to 10 statements, financial inclusion amounted to 8 statements and financial planning amounted to 12 statements. From all the statement items only one is declared invalid which in the question item financial planning variable, the corrected item-total correlation value $<\mathrm{r}$ table value of 0.3061 . Therefore, this invalid statement cannot be used in retrieving research data. The second test is the reliability test. The criteria used in the reliability test is the value of cronbach's alpha $>0.60$ in order to declare the instrument as reliable. In this study, it was obtained that all the variables studied have the value of cronbach's alpha $>0.60$.

\subsection{Normality Test}

Normal PP plot of the data spreads around the diagonal line and the distribution follows the diagonal direction, thus showing that the data on the research variables is normally distributed and suitable for use because they meet the normality assumption. On the histogram graph, a normal curve line is obtained and shows the data under study is normally distributed and worthy of use.

\subsection{Multicollinearity Test}

The regression model is considered to be free from multicollinearity if the independent research variable has a tolerance value $>0.1$ and a VIF value $<10$. The multicollinearity test results can be concluded as having no multicollinearity because tolerance value is 0.374 and thus $>0.1$ and the VIF value is 2.672 and thus $<10$. As such, the regression model is said to have passed the multicollinearity test.

\section{DISCUSSION}

\subsection{Multiple Linear Regression}

Based on the multiple value regression equation, a constant value of 0.495 is obtained, which means that if the value of the financial literacy (X1) and 
financial inclusion (X2) variables has a value equal to zero, then financial planning $(\mathrm{Y})$ has a value of 0.495 .

$\mathrm{b} 1=$ The effect of financial literacy on financial planning

The coefficient value of the financial literacy variable (X1) has a value of 0.948 , which means that if the Financial Literacy variable is increased by one percent (assuming that the value of other coefficients is constant or unchanging), there will be an increase in the value of the financial planning variable $(\mathrm{Y})$ of 0.948. The coefficient is positive, meaning that there is a positive relationship between the financial literacy variable (X1) and financial planning (Y).

$\mathrm{b} 2$ = Effect of financial inclusion on financial planning

The coefficient value of the financial inclusion variable (X2) has a value of -0.074 , which means that if the Financial Inclusion variable is increased by one percent (assuming that the value of other coefficients is constant or unchanged), there will be an increase in the value of financial planning $(\mathrm{Y})$ of -0.074 . The coefficient is negative, which means that there is a negative relationship between the financial inclusion variable (X2) and financial planning $(\mathrm{Y})$.

\subsection{Joint Hypothesis Testing (F test)}

Joint hypothesis testing is a hypothesis testing of multiple regression coefficients with X1 and X2 simultaneously affecting Y.

Based on the results of the joint hypothesis testing, the F-count value was obtained at 150.063 , while the F-table value has a significant level of $0.10 \mathrm{df}=$ $\mathrm{n}-\mathrm{k}-1=200-2-1=197$, then the F-table value was obtained at 2.330. Based on the test criteria, because the value of F-count $150.063>$ F-table 2.330, then it is concluded that financial literacy and financial inclusion have a joint effect on community financial planning in Palembang City.

The results of the F-test also show that the significant value is 0.000 . Based on the test criteria, because the sig F-is $0.000<0.10$, then there is a significant effect. So, HO is rejected and $\mathrm{Ha}$ is accepted, which means that there is a significant positive influence on financial literacy and financial inclusion on the community financial planning in Palembang. 


\subsection{Individual Hypothesis Testing ( $t$ test)}

Individual hypothesis testing is a multiple regression coefficient hypothesis testing with only one (X1) affecting Y. Based on the results of the individual hypothesis test, the $\mathrm{t}$-count value is 2.487 , while the $\mathrm{t}$-table value is significant at $0.10 \mathrm{df}=\mathrm{n}-2=200-2=198$, then the $\mathrm{t}$-table is 1.653 . Based on the test criteria, the independent variable $(\mathrm{X})$ is as follows:

1. Financial literacy variable (X1), the value of $t$-count $11.299>t$-table 1.653, and the conclusion is that financial literacy has an effect on the community financial planning in Palembang City. The t-test results also show that the significant value that appears is 0.000 . Based on the test criteria, because the sig t-value $0.000<0.10$, so there is a significant effect. So HO2.1 is rejected and Ha2.1 is accepted, which means that there is a significant positive effect of financial literacy on the community financial planning in Palembang.

2. Financial inclusion variable $(\mathrm{X} 2)$, the value of $t$-count $-0.904 \leq \mathrm{t}$-table 1.653 , so the conclusion is that financial inclusion has no effect on the community financial planning in Palembang City. The t-test results also show that the significant value is 0.541 . Based on the test criteria, because the sig t-value is $0.367 \geq 0.10$, there is no significant effect. So HO2.2 is accepted and $\mathrm{Ha} 2.2$ is rejected, which means that there is no positive effect of financial inclusion on the community financial planning in Palembang City.

\subsection{Coefficient of Determination (Adjusted Square)}

This coefficient of determination aims to determine the proportion or percentage of the total variation in the dependent variable explained by the independent variable. The adjusted $\mathrm{R}$ square is always less than $\mathrm{R}$ square and negative. For regression with more than two independent variables, adjusted $\mathrm{R}$ square is used as the coefficient of determination.

So, if the analysis used is simple, the value of $\mathrm{R}$ square is used. However, if the analysis used is multiple linear regression, then the adjusted $\mathrm{R}$ square is used.

The adjusted $\mathrm{R}$ square value is 0.600 , which means that the determination between the two independent variables together is able to have an influence on the financial planning of the people of Palembang City by $60 \%$. The remaining 
$40 \%$ is influenced by other variables that are not included in this study, namely the variable age, income, and others.

\subsection{Discussion and Comparison of Research Results}

The results showed that Palembang City Community Financial Planning is jointly influenced by financial literacy and financial inclusion. A high level of financial literacy balanced by high financial inclusion can also improve the ability of the community in managing its finances well. Therefore, it is very important for related parties, especially the city government, to further improve the level of literacy and public understanding of finance so as to create a prosperous society which is able to manage its own finances well. This research is in line with research conducted by Iko Putri Yanti W. (2019), entitled The Influence of Financial Inclusion and Financial Literacy on the Performance of MSMEs. The results of this research said that financial inclusion and financial literacy have a positive and significant influence on the performance of MSMEs.

The results of the t-test conducted in this study shows that the level of financial literacy of the community greatly influences the community in managing financial planning well, especially the understanding of finance itself. High financial knowledge and good financial skills can create good financial attitude and behavior so that people's financial confidence in managing and using financial products can be better so as to create a smart society in financial planning.

This research is in line with several previous researches, such as: first, a research by Sobaya S., Hidayanto M., Safitri J., (2016) with the title of Influence of Financial Literacy and Social Environment on Employee Financial Planning at The Islamic University of Indonesia Yogyakarta. Second, a research by Dahlia Bonang (2019) with the title of Influence of Financial Literacy on Family Financial Planning in Mataram City. Third, a study by Fakhriyah Arfianti Saputri, Rr. Iramani (2019) with the title of Influence of Financial Literacy, Personal Values, and Attitude Towards Family Financial Planning in Surabaya. The fourth is the research of Iko Putri Yanti W. (2019). These four previous researchers similarly stated that there is an influence of financial literacy on financial planning. However, the results of this study and the previous 3 studies are 
different from the research conducted by Eka Desy Purnama, Fetrik Erwanto Simarmata (2021), with the title of Lifestyle effect in moderating the influence of financial knowledge and financial literacy on financial planning. The result of his research stated that there is no influence of financial literacy on financial planning. These differences in results are likely influenced by various factors such as differences in objects studied and so on.

The results of further research show that there is no financial inclusion in financial planning. This means that financial inclusion is not the main consideration in the community to do financial planning well or not. Financial inclusion is only a tool in facilitating access to finance, including financial products (money, ATM, etc.) and financial institutions (banks, cooperatives, insurance, leasing and others). On access indicators, although financial access is easy to obtain, it is not a benchmark in financial planning. Similarly for availability indicators, although financial products and institutions are already available in the community, it is not also a determinant of a person to be able to plan his finances well. Even indicators of use and quality are not determinants in society being able to plan finances well. Therefore, financial inclusion has no effect on financial planning because inclusion is simply a tool in facilitating access and use of financial products and services.

This result is not in line with previous research conducted by Iko Putri Yanti W. (2019), which said that there is an influence of financial inclusion on financial planning.

\section{CONCLUSION}

Based on the results of testing and data analysis that have been carried out, the conclusions that can be drawn from this study are as follows:

1. The influence of financial literacy on community financial planning in Palembang City.

2. The influence of financial literacy and financial inclusion on community financial planning in Palembang City.

3. There is no influence of financial inclusion on the community financial planning in Palembang City. 


\section{REFERENCE}

Ahmad Nurul Hak, Cepy Slamet, \& Rina Kurniawati. (2014). Implementation of SMS Gateway-Based Student Financial Information Systems at SMP Muhammadiyah 2 Kadungora, Algorithm Journal of STT Garut, Vol. 11, No. 1.

Atkinson, A. \& Messy, F. (2013). Promoting Financial Inclusion through Financial Education: OECD/International Network on Financial Education (INFE) Evidence, Policies and Practice. OECD Working Papers on Finance, Insurance and Private Pensions, No. 15. Paris: OECD Publishing. Retrieved from http://dx.doi.org/10.1787/5k9csfs90fr4-en.

Australian Securities and Investment Commission (ASIC). (2014). National Financial Literacy Strategy 2014-2017. ASIC. Retrieved from http:// www.financialliteracy.gov.au/media/546585/report-403_national-financialliteracy-strategy-2014-17.pdf.

Birawani Dwi Anggraeni. (2015). The Effect of Business Owner's Financial Literacy Level on Financial Management Case Study: Depok UMKM. Jurnal Vokasi Indonesia, Vol. 4, No. 1, Pp. 43-50.

Cecep Setiawan and Kusumaningtuti S. Soetiono. (2018). Indonesian Financial Literacy and Inclusion. Depok: PT RajaGrafindo Persada.

Cochran, W.G. (1977). Sampling Techniques. New York: Jhon Wiley and Sons. Dahlia Bonang. (2019). The Effect of Financial Literacy on Family Financial Planning in Mataram City. Jurnal Iqtishaduna, Jurnal Ekonomi, dan Keuangan Islam, Vol. 4, No. 2, October 2019.

Eka Desy Purnama \& Fetrik Erwanto Simarmata. (2021). Efek Lifestyle dalam Memoderasi Pengaruh Pengetahuan Keuangan dan Literasi Keuangan terhadap Perencanaan Keuangan. Jurnal Inovasi Penelitian, Vol. 1, No. 8.

Enny Pudjiastuti \& Suad Husnan. (2016). Fundamentals of Financial Management (6th Edition). Yogyakarta: UPP STIM YKPN.

Faculty of Economics and Business, Muhammadiyah University of Palembang. (2018). Guidelines for Writing Research Proposals and Thesis (Seventh Print). Palembang: Publisher FEB-UM Palembang.

Fakhriyah Arfianti Saputri \& Rr. Iramani. (2019). Influence of Financial Literacy, Personal Values, and Attitude towards Family Financial Planning in Surabaya. Journal of Business and Banking, Vol. 9, No. 1. 
Financial Services Authority (OJK). (2013a). Indonesia's National Strategy for Financial Literacy. Jakarta: OJK.

Financial Services Authority Regulation (POJK) Number 76/POJK.07/2016 concerning Increasing Financial Literacy and Inclusion in the Financial Services Sector for Consumers and/or the Public. https://ojk.go.id/id/berita-dankegiatan/siaran-pers/Pages/Siaran-Pers-Survei-OJK-2019 Indeks-Literasi-DanInklusi-Keuangan-Meningkat.aspx.

Iko Putri Yanti W. (2019). The Influence of Financial Inclusion and Financial Literacy on MSME Performance. Jurnal Manajemen dan Bisnis, Vol. 2, No.1.

Maria Rio Rita \& Benny Santoso. (2015). Financial Literacy and Financial Planning at the Children's Education Fund. Journal of Economics, Vol. 20, No. 02.

Maya Malinda. (2018). Financial Planning. Yogyakarta: Publisher Andi.

Organization for Economic Cooperation and Development (OECD). (2005). Improving Financial Literacy: Analysis of Issues and Policies, OECD. Paris: OECD.

Palameta, B., Nguyen, C., Hui, T.S.W., \& Gyarmati, D. (2016). The link between financial confidence and financial outcomes among working-aged Canadians. The Social Research and Demonstration Corporation (SRDC).

Presidential Regulation Number 82 of 2016 (PP_2016) concerning Inclusive Financial Strategy.

Prita Hapsari Ghozie. (2019). Make It Happen! Smart Book of Financial Plans to Realize Dreams (7th Printing) Jakarta: Gramedia Pustaka Utama.

Riduwan. (2013). Methods and Techniques for Composing a Thesis (9th Printing). Bandung: Alfabeta.

R. Lukmanto. (2014). A Descriptive Study of Student Perceptions about Student Financial Planning in Surabaya. University of Surabaya Student Scientific Journal, Vol. 3, No. 1.

Senduk, S. (2009). Family Financial Planning Series. Jakarta: Elex Media Komputindo.

Sikapiuangmu.ojk.go.id. What is a Financial Plan? Accessed on 09/12/2019. Retrieved from https://sikapiuangmu.ojk.go.id/FrontEnd/CMS/Category/130. 
Soya Sobaya, M. Fajar Hidayanto, \& Junaidi Safitri. (2016). The Effect of Financial Literacy and the Social Environment on Employee Financial Planning at the Islamic University of Indonesia Yogyakarta. Madania Islamic Studies Journal, Vol. 20, No. 1.

Sugiyono. (2012). Metode Penelitian Bisnis. Bandung: Alfabeta.

Suliyanto. (2018). Metode Penelitian Bisnis. Purwokerto: Penerbit Andi.

Wibawa, H.K. (2003). Perencanaan Kenangan Keluarga. Jakarta: Salemba Empat.

World Bank. (2010). Improving Access to Financial Services in Indonesia. Jakarta: The World Bank.

. (2014a). Financial Education Programs and Strategies: Approaches and Available Resources, January 2014.

. (2014b). Financial Inclusion. Global Financial Development Report. Jakarta: The World Bank.

. (2019b). National Survey of Indonesian Financial Literacy.

Jakarta: OJK. 